\title{
Analisis Perbandingan Kinerja Keuangan Bank Umum Syariah Hasil Spin-Off dan Hasil Akuisisi
}

\author{
Comparative analysis of the financial performance of Islamic commercial banks from the spin-off \\ and acquistion
}

\author{
Bagus Jaya Firdaus \\ Program Studi D4 Keuangan Syariah, Politeknik Negeri Bandung \\ E-mail: bagus.firdaus.ksy15@polban.ac.id
}

\section{Diharpi Herli Setyowati}

Jurusan Akuntansi, Politeknik Negeri Bandung

E-mail: diharpi.herli@polban.ac.id

\begin{abstract}
This research is a study that compares the financial performance of Sharia Commercial Bank spin-off and acquisition. This research used BJB Syariah Bank and BNI Syariah Bank as a sample from Syariah Bank of spin-off result meanwhile Bank BRI Syariah, Bank BCA Syariah, and Bank Syariah Bukopin as sample from Sharia Public Bank of acquisition result. This research uses annual data for the period 2015-2017. Data analysis technique used is different test by using bypothesis test Independent Sample T-Test and the Mann Whitney U Test. The results of this study indicate that from the results of different tests there is no significant difference from the financial performance of the Islamic Commercial Banks resulting from spin-offs and the results of Acquisitions in financial ratios $C A R, R O A, F D R, N P F$, and $B O P O$.
\end{abstract}

Keywords: Financial Performance, Acquisition, Spin-Off

\section{Pendahuluan}

Pertumbuhan Bank Syariah di Indonesia saat ini cukup pesat dan yang menjadikan pertumbuhan perbankan syariah di Indonesia ini pesat diantaranya adalah kebijakan yang dilakukan oleh pemerintah. Pemerintah terus mengembangkan perbankan syariah di Indonesia karena perbankan syariah di Indonesia memiliki potensi yang sangat besar karena 90\% dari jumlah penduduk di Indonesia beragama Islam sehingga pemerintah ingin memberikan pelayanan perbankan yang sesuai dengan syariat Islam.

Dalam mengembangkan industri perbankan syariah di Indonesia, Bank Indonesia telah menyusun cetak biru pengembangan industri perbankan syariah pada tahun 2002 dan edisi revisinya pada tahun 2005-2006 (Ismal, 2011), selain itu Bank Indonesia bekerjasama dengan seluruh pemangku kepentingan di industri perbankan syariah menyusun suatu program percepatan pada tahun 2007-2008, dimana program ini berkonsentrasi pada pencapaian pangsa pasar sebesar 5\% pada akhir tahun 2008, namun kenyataanya pada akhir tahun 2008, pencapaian pangsa pasar hanya mencapai $2.10 \%$ saja. Belum tercapainya target ini menjadikan Bank Indonesia mengubah target pangsa pasar pada akhir tahun 2009 diharapkan pangsa pasartelah mencapai 3.5\%, dan pada akhir tahun 2010 telah mencapai 4.75\% (Ismal, 2011) namun, sampai dengan akhir tahun 2014, target pangsa pasar sebesar 5\% pun belum tercapai, sehingga memunculkan istilah "five percent trap" di kalangan industri perbankan syariah atas belum tercapainya target tersebut.

Salah satu upaya yang di lakukan pemerintah adalah dengan menerbitkan Undang- 
Undang No. 21 Tahun 2008 tentang Perbankan Syariah.Pemerintah melalui Undang-Undang Nomor 21 tahun 2008 tentang Perbankan Syariah telah mewajibkan Bank Umum Konvensional (BUK) untuk melakukan pemisahan terhadap Unit Usaha Syariah (UUS) agar berdiri sendiri menjadi Bank Umum Syariah (BUS). Hal tersebut diungkapkan lebih jelas dalam Undang-Undang tersebut pasal 68 ayat 1 yang berbunyi sebagai berikut.

Bank Umum Konvensional yang memiliki Unit Usaha Syariah yang nilai asetnya telah mencapai paling sedikit 50\% (lima puluh persen) dari total nilai aset bank induknya atau 15 (lima belas) tahun sejak berlakunya Undang-Undang ini, maka Bank Umum Konvensional yang dimaksud wajib melakukan pemisahan Unit Usaha Syariah tersebut menjadi Bank Umum Syariah (UU No. 21 Tahun 2008 Pasal 68, Ayat 1), dari undang-undang tersebut dapat kita ketahui bahwa jika ada Unit Usaha Syariah yang memiliki nilai aset minimal 50\% dari total nilai aset bank induk konvensionalnya maka Unit Usaha Syariah tersebut wajib memisahkan diri dan menjadi Bank Umum Syariah, dan jika ada Unit Usaha Syariah yang masih menginduk pada Bank Umum Konvensional 15 tahun sejak berlakunya undang- undang ini maka Unit Usaha Syariah tersebut wajib memisihakan diri juga.

Tabel 1. Nama Bank Umum Syariah, Cara Pendirian dan Tahun Didirikan

\begin{tabular}{|c|l|l|c|}
\hline No & \multicolumn{1}{|c|}{ Nama Bank } & \multicolumn{1}{|c|}{ Cara Pendirian } & $\begin{array}{c}\text { Tahun } \\
\text { Pendirian }\end{array}$ \\
\hline 1 & PT. Bank Muamalat Indonesia, & Pendirian dari awal & 1991 \\
\hline 2 & PT. Bank Syariah Mandiri & Konversi PT Bank Susila Bakti & 1999 \\
\hline 3 & PT. Bank Mega Syariah Indonesia & Konversi PT Bank Umum Tugu & 2004 \\
\hline 4 & PT. Bank BRISyariah & Akuisisi PT Bank Jasa Arta & 2008 \\
\hline 5 & PT. Bank Syariah Bukopin & $\begin{array}{l}\text { Akuisisi PT Bank Persyarikatan } \\
\text { Indonesia }\end{array}$ & 2008 \\
\hline 6 & PT. Bank Panin Dubai Syariah, & Konversi PT Bank Harfa & 2009 \\
\hline 7 & PT. Bank Victoria Syariah & Konversi PT Bank Swaguna & 2010 \\
\hline 8 & PT. BCA Syariah & Akuisisi PT Bank UIB & 2010 \\
\hline 9 & PT. Bank Jabar Banten Syariah & Spin-off UUS BJB & 2010 \\
\hline 10 & PT. BNI Syariah & Spin-off UUS BNI & 2010 \\
\hline 11 & PT. Maybank Syariah Indonesia & Konversi PT Bank Maybank & 2010 \\
\hline 12 & $\begin{array}{l}\text { PT. Bank Tabungan Pensiunan } \\
\text { Nasional Syariah }\end{array}$ & $\begin{array}{l}\text { Konversi PT Bank Sahabat } \\
\text { Purbadanarta }\end{array}$ & 2014 \\
\hline 13 & PT. Bank Aceh Syariah & Konversi PT. Bank Aceh & 2016 \\
\hline
\end{tabular}

Sumber : website masing masing bank syariah

Dapat dilihat dari tabel 1 dari 13 Bank Umum Syariah yang didirikan Indonesia. Pada periode 1991-2008 dalam jangka waktu delapan belas tahun hanya tiga bank syariah yang didirikan di Indonesisa yaitu Bank Muamalat, Bank Syariah Mandiri dan Bank Mega Syariah, namun pada tahun 2008-2018 pendirian bank di Indonesia mengalami peningkatan yang pesat dalam jangka waktu sepuluh tahun terdapat sepuluh pendirian Bank Umum Syariah di Indonesia. Hal ini merupakan salah satu dampak dari diterapkannya Undang-Undang Nomor 21 tahun 2008 yang bersifat memaksa Bank Konvensional yang memiliki Unit Usaha Syariah untuk segera memisahkan kegiatan operasionalnya.

Dari tabel 1 dapat kita lihat cara pendirian bank di Indonesia dapat dilakukan dengan empat 
cara yaitu pendirian dari awal, spin-off, akuisisi, dan konversi. Dimana penjelasan singkat dari pendirian dari awal yaitu bank umum syariah didirikan dengan cara mendirikan badan hukum usaha benar-benar dari awal atau dari nol. Spin-off pendirian bank umum syariah dengan cara melakukan pemisahan unit usaha syariah dari bank umum konvensional menjadi bank umum syariah dengan membuat badan hukum usaha baru. Akuisisi cara pendirian bank umum syariah dengan cara membeli badan hukum usaha yang sudah ada lalu operasionalnya dijadikan bank umum syariah. Konversi secara teknis konversi diatur dalam Pasal 2 PBI No.8/3/PBI/2006 yang intinya menyatakan bahwa bank hanya dapat mengubah kegiatan usahanya menjadi bank yang melaksanakan kegiatan usaha berdasarkan perinsip syariah dengan izin dari Gubernur Bank Indonesia, dimana rencana tersebut wajib dicantumkan dalam rencana bisnis bank . (Umam,2015)

Menurut para ahli penerapan Undang-Undang Nomor 21 tahun 2008 memiliki beberapa dampak negatif, pertama berdampak pada kepercayaan masyarakat terhadap Bank Syariah, dengan diberlakukan Undang-Undang Nomor 21 tahun 2008 maka pemisahan Unit Usaha Syariah menjadi Bank Umum Syariah cenderung dipaksakan sehingga kegiatan operasional Bank Syariah masih bergantung pada Bank induk konvensionalnya, oleh karena itu tingkat kepercayaan masyarakat pada Bank Syariah masih rendah karena menganggap operasional Bank Syariah dengan Bank Konvensional cenderung sama. Kedua penerapan Undang-Undang Nomor 21 tahun 2008 dapat mempengaruhi kinerja keuangan Bank Syariah karena pemisahan yang banyak terjadi pada periode 2008-2010 yaitu sebanyak delapan bank terkesan dipaksa di percepat sehingga dapat berdampak pada kinerja keuangan Bank Syariah.

Tabel 2. Rasio keuangan Bank Umum Syariah hasil Spin-off Periode 2015-2017

\begin{tabular}{|c|c|c|c|c|c|c|}
\hline \multirow{3}{*}{ Rasio } & \multicolumn{6}{|c|}{ Bank spin-off (\%) } \\
\cline { 2 - 7 } & \multicolumn{4}{|c|}{ BJB Syariah } & \multicolumn{3}{c|}{ BNI Syariah } \\
\cline { 2 - 7 } & 2015 & 2016 & 2017 & 2015 & 2016 & 2017 \\
\hline CAR & 22.5 & 18,2 & 16,2 & 15,4 & 14,9 & 20,1 \\
\hline ROA & 0.25 & $-8,09$ & $-5,69$ & 1,4 & 1,4 & 1,3 \\
\hline FDR & 104,7 & 98,7 & 91,3 & 91,9 & 84,5 & 80,2 \\
\hline NPF & 4.4 & 2,8 & 4,5 & 1.4 & 1,6 & 1,5 \\
\hline BOPO & 98.78 & 122,7 & 134,6 & 89.6 & 86,8 & 87,6 \\
\hline
\end{tabular}

Sumber: Laporan Tabunan Masing-Masing Bank Syariah Data di olab kembali

Tabel 3. Rasio keuangan Bank Umum Syariah Hasil Akuisisi Periode 2015-2017

\begin{tabular}{|c|c|c|c|c|c|c|c|c|c|}
\hline \multirow{3}{*}{ Rasio } & \multicolumn{9}{|c|}{ Bank Akuisisi (\%) } \\
\cline { 2 - 11 } & \multicolumn{3}{|c|}{ BCA Syariah } & \multicolumn{3}{c|}{ BRI Syariah } & \multicolumn{3}{c|}{ Bukopin Syariah } \\
\cline { 2 - 11 } & 2015 & 2016 & 2017 & 2015 & 2016 & 2017 & 2015 & 2016 & 2017 \\
\hline CAR & 29,4 & 36,7 & 34,3 & 13,9 & 20,6 & 20,2 & 16,3 & 17,0 & 19,2 \\
\hline ROA & 1,2 & 1,1 & 1,0 & 0,77 & 0,95 & 0,51 & 0,79 & 0,76 & 0,02 \\
\hline FDR & 91,4 & 90,1 & 88,5 & 84,1 & 81,4 & 71,8 & 90,5 & 88,1 & 82,4 \\
\hline NPF & 0,3 & 0,5 & 0,7 & 3,8 & 3,1 & 4,7 & 2,74 & 2,72 & 4,18 \\
\hline BOPO & 87,2 & 92,2 & 92,5 & 93,7 & 91,3 & 95,2 & 91,9 & 91,7 & 99,2 \\
\hline
\end{tabular}

Sumber: Laporan Tabunan Masing-Masing Bank Syariah Data di olah kembali

Dari tabel 2 dan 3 menunjukan bahwa sekilas tidak terdapat perbedaan yang singnifikan antara Bank Umum Syariah hasil akuisisi dengan Bank Umum Syariah hasil akuisisi, tapi jika dilihat dari kenaikan kinerja keuangan setiap tahunnya Bank Umum Syariah hasil akuisisi mengalami kenaikan rasio keuangan yang lebih baik di banding Bank Umum Syariah hasil Spin-off. 
Penelitian yang dilakukan oleh Saraya Izazi. S. H. dan Dina Fitrisia. S. (2016), dengan judul Analisis Perbandingan Kinerja Keuangan Bank Umum Syariah Hasil Spin-off dan Hasil Non Spinoff periode 2013-2015, menunjukkan bahwa rasio CAR tidak terdapat perbedaan kinerja keuangan antara BUS hasil spin-off dan hasil akuisisi sedangkan untuk rasio NPF, ROA, BOPO, FDR terdapat perbedaan kinerja keuangan antara BUS hasil spin-off dan hasil akuisisi.

Terkait dengan pendekatan atau tipe dalam pemisahan unit usaha syariah menjadi bank umum syariah, Rizqullah (2013) dalam kajian yang dilakukan menunjukkan bahwa metode pemisahan unit usaha syariah menjadi bank umum syariah yang paling baik ialah dengan membentuk badan perusahaan baru atau dengan cara melakukan pemisahan murni karena tipe pemisahan ini lebih praktis dibandingkan dengan pemisahan menggunakan badan hukum yang sudah ada. Urutan alternatif pendirian berikutnya ialah pemisahan dengan menggunakan badan hukum yang sudah ada.

Berdasarkan latar belakang tersebut maka penulis tertarik melakukan penelitian yang bertujuan untuk membandingkan kinerja keuangan perbankan syariah hasil spin-off dan hasil akuisisi, sehingga melalui hasil penelitian dapat diketahui apakah hasil spin-off atau hasil akuisisi yang dapat memaksimalkan kinerja keuangan Bank Umum Syariah tersebut. Sehingga Bank Umum Konvensional yang belum dan akan melakukan pemisahan menjadi Syariah dapat memilih manakah yang lebih baik. Maka dari itu penulis akan melakukan peneitian yang berjudul Analisis Perbandingan Kinerja Keuangan Bank Umum Syariah Hasil Spin-Off dan Hasil Akuisisi.

\section{Kajian Pustaka}

\subsection{Spin-off}

Spin-off diartikan sebagai pemisahan usaha dari satu BUK (Bank Umum Konvensional) menjadi dua badan usaha atau lebih sesuai dengan ketentuan peraturan perundang-undangan yang berlaku (Setiawan \& Sari, 2018).

\subsection{Akuisisi}

Kegiatan akuisisi pada dasarnya adalah pengambilalihan saham sehingga kepemilikan perseroan beralih kepada pihak lain (Nurdin et al., 2020). Saham perseroan dapat diambil seluruhnya atau sebagian besar. Oleh karena itu, pengambilan dapat mengakibatkan beralihnya pengendalian terhadap perseroan, yaitu mempengaruhi jalanya perseroan (Umam,2015)

Proses pengambilalihan kepemilikan dari dasar hukum syariah adalah kegiatan jual beli, pengambilalihan ini disamakan dengan kegiatan jual beli sehingga dasar hukum islam yang digunakan dalam akuisisi adalah dasar hukum fiqih muamalah dimana dasar hukum jual beli mempunyai landasasn yang kuat dalam al-Quran dan sunah Rasulullah SAW. Terdapat beberapa ayat al-Quran dan sunah yang membahas tentang jual beli ini, antara lain:

1. Surat al-Baqarah ayat 275 :

أَحَلَّ اللَّه الْبَيْعَ وَحَرََّمَ الرِّبَا....

Allah menghalalkan jual beli dan mengharamkan riba ...

2. Surat an-Nisa ayat 29:

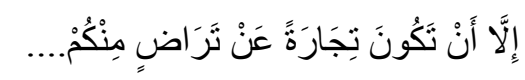

... kecuali dengan jalan perniagaan yang berlaku dengan suka sama suka di antara kamu ... 
3. Hadis dari al-Baihaqi, Ibn Majah dan Ibn Hibban, Rasulullah menyatakan:

"Iual beli itu didasarkan atas suka sama suka".

Akuisisi yang dapat dikatakan sebagai transaksi jual beli harus memenuhi rukun dan syarat fiqih muamalah agar akuisisi tersebut dapat dikatakan sah oleh Syara' Dalam menentukan rukun jual beli terdapat perbedaan pendapat antara ulama Hanafiyah dengan jumhur ulama. Rukun jual beli menurut ulama Hanafiyah hanya satu yaitu ijab dan kabul, namun jumhur ulama menyatakan bahwa rukun jual beli ada empat, yaitu: (Ghazaly, 2010)

1. Orang yang berakad al-muta'aqidain (penjual dan pembeli).

2. Ada shighat (lafal ijab dan kabul).

3. Ada barang yang di beli.

4. Ada nilai tukar pengganti barang.

\section{Metode Penelitian}

Jenis penelitian yang dilakukan dalam penelitian ini yaitu penelitian komparatif data kuantitatif kinerja keuangan Bank Umum Syariah hasil spin-offdan akuisisi, dengan populsi tiga belas Bank Umum Syariah yang ada di Indonesia dan metode pengambilan sampel yang digunakan dalam penelitian ini yaitu proposing sample atau pengambilan sampel dengan kriteria tertentu.

Kriteria sampel yang digunakan dalam penelitian ini yaitu Bank Umum Syariah yang didirikan dengan cara spin-off dan akuisisi, Bank Umum Syariah hasil spin-off dan akuisisi yang mempublikasikan laporan keuanganya pada periode 2015-2017,

Alat uji yang digunakan dalam penelitian ini yaitu SPSS 23 dengan menggunakan metode komparatif, langkah awal dalam pengujian uji beda ini yaitu dilakukan uji normalitas terlebih dahulu lalu ketika data dinyatakan normal maka pengujian dilanjutkan dengan uji independent $T$ test, namun jika data tidak terdistribusi normal maka penelitian dilanjutkan dengan uji Mann-Whitney U test.

\section{Hasil dan Pembahasan}

Tabel 4. Gambaran Umum Bank Syariah hasil Spin-off

\begin{tabular}{|c|c|c|c|}
\hline Nama Bank & $\begin{array}{c}\text { Thun Pendirian } \\
\text { UUS }\end{array}$ & $\begin{array}{c}\text { Tahun Pendirian } \\
\text { BUS }\end{array}$ & Kepemilikan Saham \\
\hline PT. BNI Syariah & 2000 & 2010 & $\begin{aligned} 99,94 \%= & \text { PT BNI } \\
0,06 \%= & \text { PT BNI Life } \\
& \text { Insurance }\end{aligned}$ \\
\hline PT. BJB Syariah & 2000 & 2010 & $\begin{array}{ll}99 \% & =\text { PT BJB } \\
1 \% & = \\
& \text { PT Banten Global } \\
& \text { Develovment }\end{array}$ \\
\hline
\end{tabular}

Sumber : website masing masing bank syariah

Tabel 5. Gambaran Umum Bank Syariah hasil Akuisisi

\begin{tabular}{|c|c|c|c|}
\hline Nama Bank & Asal Bank & $\begin{array}{c}\text { Tahun Pendirian } \\
\text { BUS }\end{array}$ & Kepemilikan Saham \\
\hline \multirow{2}{*}{ PT. BRI Syariah } & $\begin{array}{c}\text { PT Bank Jasa } \\
\text { Arta }\end{array}$ & 2008 & $\begin{array}{l}73 \%=\text { PT BRI } \\
17,4 \%=\text { Publik } \\
9,9 \%=\text { Yayasan Kesejahteraan } \\
\text { Pekerja BRI }\end{array}$ \\
\hline PT. BCA Syariah & PT Bank UIB & 2010 & $\begin{array}{l}99 \%=\text { PT BCA } \\
0,1 \%=\text { PT BCA Finance }\end{array}$ \\
\hline
\end{tabular}




\begin{tabular}{|c|c|c|c|c|}
\hline $\begin{array}{c}\text { PT Bank Syariah } \\
\text { Bukopin }\end{array}$ & $\begin{array}{c}\text { PT Bank } \\
\text { Persyarikatan } \\
\text { Indonesia }\end{array}$ & 2008 & $\begin{array}{l}92 \% \\
2 \% \\
2 \% \\
2 \% \\
2 \%\end{array}$ & $\begin{array}{l}=\text { PT Bank Bukopin } \\
=\text { PT Mega Sekuritas } \\
=\text { PT Bakrie Sekuritas } \\
=\text { BPJS Ketenagakerjaan } \\
=\text { PT Mitra Sarana Usaha }\end{array}$ \\
\hline
\end{tabular}

Sumber : website masing masing bank syariah

Tabel 6. Uji Normalitas

\begin{tabular}{|l|r|r|r|r|r|r|}
\hline \multirow{2}{*}{} & \multicolumn{4}{|c|}{ Kolmogorov-Smirnova $^{\mathrm{a}}$} & \multicolumn{3}{|c|}{ Shapiro-Wilk } \\
\cline { 2 - 7 } & Statistic & $\mathrm{df}$ & \multicolumn{1}{c|}{ Sig. } & Statistic & Df & \multicolumn{1}{c|}{ Sig. } \\
\hline Car &, 256 & 15 &, 009 &, 821 & 15 &, 007 \\
Roa &, 392 & 15 &, 000 &, 560 & 15 &, 000 \\
Fdr &, 176 & 15 &, $200^{*}$ &, 967 & 15 &, 807 \\
Npf &, 143 & 15 &, $200^{*}$ &, 925 & 15 &, 227 \\
Bopo &, 302 & 15 &, 001 &, 677 & 15 &, 000 \\
\hline
\end{tabular}

Sumber : Data sekunder yang diolah

- Variabel CAR bank syariah hasil Spin-off dan hasil akuisisi setelah di uji Kolomogrov-Smirnov nilai sig. sebesar 0,009 >0,05 maka $\mathrm{H}_{0}$ ditolak dan data variabel CAR tidak terdistribusi normal

- Variabel ROA bank syariah hasil Spin-off dan hasil akuisisi setelah di uji Kolomogrov-Smirnov nilai sig. sebesar $0,00<0,05$ maka $\mathrm{H}_{0}$ ditolak dan data variabel $\mathrm{ROA}$ tidak terdistribusi normal

- Variabel FDR bank syariah hasil Spin-off dan hasil akuisisi setelah di uji Kolomogrov-Smirnov nilai sig. sebesar 0,2 > 0,05 maka $\mathrm{H}_{0}$ diterima dan data variabel FDR terdistribusi normal

- Variabel NPF bank syariah hasil Spin-off dan hasil akuisisi setelah di uji Kolomogrov-Smirnov nilai sig. sebesar 0,2 > 0,05 maka Ho diterima dan data variabel NPF terdistribusi normal

- Variabel BOPO bank syariah hasil Spin-off dan hasil akuisisi setelah di uji Kolomogrov-Smirnov nilai sig. sebesar $0,00<0,05$ maka $\mathrm{H}_{0}$ ditolak dan data variabel $\mathrm{BOPO}$ tidak terdistribusi normal

Dari Uji normalitas tersebut yang di uji menggunakan SPSS pada uji Kolomogrov-Smirnov dapat di llihat bahwa nilai sig. FDR dan NFP $>0,05$ maka data terdistribusi normal dan untuk pengujian beda dapat dilakukkan uji beda parametik menggunakan uji Independent sample $T$ Test. Hasil uji normalitas untuk variabel CAR, ROA, dan BOPO $<0,05$ maka data tidak normal dan untuk pengujian uji bedanya menggunakan uji beda non parametik menggunakan uji beda Man whitney.

Tabel 7. Hasil Uji Beda Kinerja Keuangan Bank Umum Syariah Hasil Spin-off dan Bank Umum Syariah Hasil Akuisisi

\begin{tabular}{|c|c|c|c|}
\hline Variabel & Teknik Uji & Nilai Statistik & Hasil \\
\hline CAR & Mann-Whitney & $0,195>0,05$ & $\begin{array}{c}\text { Tidak terdapat } \\
\text { perbedaan signifikan }\end{array}$ \\
\hline ROA & Mann-Whitney & $0,906>0,05$ & Tidak terdapat \\
\hline
\end{tabular}




\begin{tabular}{|c|c|c|c|}
\hline & & & perbedaan signifikan \\
\hline FDR & Independent T Test & $0,469>0,05$ & $\begin{array}{c}\text { Tidak terdapat } \\
\text { perbedaan signifikan }\end{array}$ \\
\hline NPF & Independent T Test & $0,708>0,05$ & $\begin{array}{c}\text { Tidak terdapat } \\
\text { perbedaan signifikan }\end{array}$ \\
\hline BOPO & Mann-Whitney & $0,906>0,05$ & $\begin{array}{c}\text { Tidak terdapat } \\
\text { perbedaan signifikan }\end{array}$ \\
\hline
\end{tabular}

Sumber: Data sekunder yang diolah

Hasil penelitian ini mengenai uji beda kinerja keuangan rasio CAR yang menggunakan alat SPSS dengan uji beda Mann-Whitney menunjukan hasil bahwa tidak terdapat perbedaan yang signifikan antara CAR Bank Umum Syariah Hasil Spin-off dan Akuisisi. Hasil Penelitian ini mendukung penelitian sebelumnya oleh Saraya Izazi dan Dina Fitrisia (2016)yang menyatakan bahwa tidak terdapat perbedaan pada rasio CAR Bank Umum Syariah Hasil Spin-off dan Akuisisi,dan M Nur Rianto Al Arif, Endah Putri Dewanti pada penelitiannya menyatakan Metode pemisahan tidak berdampak pada tingkat profitabilitas di bank umum syariah hasil pemisahan hanya NPF dan BOPO yang berpengaruh pada tingkat Profitabulitas .

Besarnya minimal Capital Adequacy Ratio (CAR) minimal 8\% ditetapkan oleh Banking for International Settlement(BIS), jika CAR berada dibawah 8\% maka dari sektor permodalan bank tersebut dapat dikategorikan tidak sehat. Ketentuan CAR minimal 8\% diadopsi oleh Bank Indonesia yang menetapkan Kewajiban Penyediaan Modal Minimum (KPMM) bank dalam Peraturan Bank Indonesia Nomor 14/18/PBI/2012 tentang Kewajiban Penyediaan Modal Minimum. Nilai rata-rata rasio Bank Umum Syariah Hasil Spin-off dan Akuisisi keduanya berada di atas $8 \%$ sehingga walaupun tidak terdapat perbedaan yang signifikan rasio CAR Bank Umum Syariah Hasil Spin-off dan Akuisisi dapat dikategorikan sehat.

Hasil penelitian ini mengenai uji beda kinerja keuangan rasio ROA yang menggunakan alat SPSS dengan uji beda Mann-Whitney U Test menunjkan hasil bahwa tidak terdapat perbedaan yang signifikan antara ROA Bank Umum Syariah Hasil Spin-off dan Akuisisi. Hasil Penelitian ini mendukung penelitian sebelumnya oleh Saraya Izazi dan Dina Fitrisia (2016) yang menyatakan bahwa tidak terdapat perbedaan pada rasio CAR Bank Umum Syariah Hasil Spin-off dan Akuisisi.

Lampiran Surat Edaran Bank Indonesia nomor 13/24/DPN lampiran 6.1 tentang matriks perhitungan/analisis komponen faktor rentabilitas (earning). Tujuan menghitung ROA adalah untuk mengukur keberhasilan manajemen dalam menghasilkan laba. Semakin kecil rasio ini mengindikasikan kurangnya kemampuan manajemen bank dalam hal mengelola aktiva untuk meningkatkan pendapatan atau menekan biaya. Kriteria penelian minimum untuk rasio ROA adalah ROA $\leq 0 \%$. Nilai rata-rata ROA Bank Umum Syariah hasil Spin-off sebesar $-1,5 \leq 0 \%$ maka ini dapat dikategorikan tidak sehat sedangkan nilai rata-rata ROA Bank Umum Syariah hasil akuisisi bernilai $0,78 \geq 0 \%$ dikategorikan baik atau sehat, maka walaupun dari hasil uji beda menyatakan tidak terdapat perbedaan yang signifikan tapi jika dilihat dari nilai rata-ratanya Bank Umum Syariah hasil akuisisi masih lebih baik dibanding dengan Bank Umum Syariah hasil Spin-off .

Hasil penelitian ini mengenai uji beda kinerja keuangan rasio FDR yang menggunakan alat SPSS dengan uji beda Independent T Test menunjkan hasil bahwa tidak terdapat perbedaan yang signifikan antara FDR Bank Umum Syariah Hasil Spin-off dan Akuisisi. Hasil Penelitian ini mendukung penelitian sebelumnya oleh Saraya Izazi dan Dina Fitrisia (2016) yang menyatakan bahwa tidak terdapat perbedaan pada rasio CAR Bank Umum Syariah Hasil Spin-off dan Akuisisi dan M Nur Rianto Al Arif, Endah Putri Dewanti pada penelitiannya menyatakan Metode pemisahan tidak berdampak pada tingkat profitabilitas di bank umum syariah hasil pemisahan hanya NPF dan BOPO yang berpengaruh pada tingkat Profitabulitas . 
Financing to Deposit Ratio (FDR) merupakan rasio yang mengukur kemampuan perbankan dalam memenuhi kewajiban jangka pendeknya atau biasa di sebut likiuditas dimana rasio ini di hitung dengan cara membandingkan pembiayaan yang disalurkan pada nasabah terhadap dana pihak ketiga yang dihimpun dari nasabah. Nilai rata-rata FDR Bank Umum Syariah hasil Spin-off lebih besar dibanding nilai rata-rata FDR Bank Umum Syariah hasil berarti porsi pembiayaan yang disalurkan oleh BUS Spin-off lebih besar dan berarti lebih baik, namun pembiayaan besar yang disalurkan ini dapat menjadi resiko yang besar pula ketika terjadi kredit macet maka nilai NPF akan semakin besar pula.

Hasil penelitian ini mengenai uji beda kinerja keuangan rasio NPF yang menggunakan alat SPSS dengan uji beda Independent $T$ Test menunjkan hasil bahwa tidak terdapat perbedaan yang signifikan antara NPF Bank Umum Syariah Hasil Spin-off dan Akuisisi. Hasil Penelitian ini mendukung penelitian sebelumnya oleh Saraya Izazi dan Dina Fitrisia (2016) yang menyatakan bahwa tidak terdapat perbedaan pada rasio CAR Bank Umum Syariah Hasil Spin-off dan Akuisisi.

Lampiran Surat Edaran Bank Indonesia nomor 13/24/DPN lampiran 6.1 tentang matriks perhitungan/analisis komponen faktor rentabilitas (earning). Tujian untuk mengukur NPF adalah untuk mengukur tingkat permasalahan Pembiayaan yang dihadapi oleh bank. Semakin tinggi rasio ini, menunjukkan kualitas Pembiayaan bank syariah semakin buruk. Keriteria penilaian untuk rasio NPF sehat adalah NPF $\leq 12 \%$. Karena nilai NPF Bank Umum Syariah Hasil Spin-off dan Akuisisi tdak ada yang lebih dari $12 \%$ sehingga walaupun tidak terdapat perbedaan yang signifikan rasio NPF Bank Umum Syariah Hasil Spin-off dan Akuisisi dapat dikategorikan sehat.

Hasil penelitian ini mengenai uji beda kinerja keuangan rasio BOPO yang menggunakan alat SPSS dengan uji beda Mann-Whitney U Test menunjkan hasil bahwa tidak terdapat perbedaan yang signifikan antara BOPO Bank Umum Syariah Hasil Spin-off dan Akuisisi. Hasil Penelitian ini mendukung penelitian sebelumnya oleh Saraya Izazi dan Dina Fitrisia (2016) yang menyatakan bahwa tidak terdapat perbedaan pada rasio CAR Bank Umum Syariah Hasil Spin-off dan Akuisisi.

Lampiran Surat Edaran Bank Indonesia nomor 13/24/DPN lampiran 6.1 tentang matriks perhitungan/analisis komponen faktor rentabilitas (earning). Tujuan menghitung BOPO adalah untuk Mengukur efisiensi kegiatan operasional bank syariah. Penentuan kriteria sehat untuk BOPO adalah BOPO < 89\%. Nilai rata-rata BOPO Bank Umum Syariah hasil Spin-off sebesar 103,3\% maka ini dapat dikategorikan tidak sehat sedangkan nilai rata-rata ROA Bank Umum Syariah hasil akuisisi bernilai $92,7 \%$ dikategorikan kurang baik, maka walaupun dari hasil uji beda menyatakan tidak terdapat perbedaan yang signifikan tapi jika dilihat dari nilai rata-ratanya Bank Umum Syariah hasil akuisisi masih lebih baik dibanding dengan Bank Umum Syariah hasil Spin-off.

Tabel 8. Kinerja Keuangan Bank Umum Syariah Hasil Spin-off

\begin{tabular}{|c|c|c|c|c|c|c|c|c|c|}
\hline \multirow{3}{*}{ Rasio } & \multicolumn{6}{|c|}{ Bank Spin-off (\%) } & \multirow{3}{*}{ Mean } & \multirow{3}{*}{ Min } & \multirow{3}{*}{ Max } \\
\hline & \multicolumn{3}{|c|}{ BJB Syariah } & \multicolumn{3}{|c|}{ BNI Syariah } & & & \\
\hline & 2015 & 2016 & 2017 & 2015 & 2016 & 2017 & & & \\
\hline CAR & 22.5 & 18,2 & 16,2 & 15,4 & 14,9 & 20,1 & 17,8 & 14,9 & 22,5 \\
\hline $\mathrm{ROA}$ & 0.25 & $-8,09$ & $-5,69$ & 1,4 & 1,4 & 1,3 & $-1,5$ & $-8,09$ & 1,4 \\
\hline FDR & 104,7 & 98,7 & 91,3 & 91,9 & 84,5 & 80,2 & 91,8 & 80,2 & 104,7 \\
\hline NPF & 4.4 & 2,8 & 4,5 & 1.4 & 1,6 & 1,5 & 2,7 & 1,4 & 4,5 \\
\hline BOPO & 98.78 & 122,7 & 134,6 & 89.6 & 86,8 & 87,6 & 103,3 & 86,8 & 134,6 \\
\hline
\end{tabular}

Sumber: Data sekunder yang diolah 
Tabel 9. Kinerja Keuangan Bank Umum Syariah Hasil Akuisisi

\begin{tabular}{|c|c|c|c|c|c|c|c|c|c|c|c|c|}
\hline \multirow{3}{*}{ Rasio } & \multicolumn{9}{|c|}{ Bank Akuisisi (\%) } & \multirow{3}{*}{ Mean } & \multirow{3}{*}{ Min } & \multirow{3}{*}{ Max } \\
\hline & \multicolumn{3}{|c|}{ BCA Syariah } & \multicolumn{3}{|c|}{ BRI Syariah } & \multicolumn{3}{|c|}{ Bukopin Syariah } & & & \\
\hline & 2015 & 2016 & 2017 & 2015 & 2016 & 2017 & 2015 & 2016 & 2017 & & & \\
\hline CAR & 29,4 & 36,7 & 34,3 & 13,9 & 20,6 & 20,2 & 16,3 & 17,0 & 19,2 & 23 & 13,9 & 36,7 \\
\hline $\mathrm{ROA}$ & 1,2 & 1,1 & 1,0 & 0,77 & 0,95 & 0,51 & 0,79 & 0,76 & 0,02 & 0,78 & 0,02 & 1,2 \\
\hline FDR & 91,4 & 90,1 & 88,5 & 84,1 & 81,4 & 71,8 & 90,5 & 88,1 & 82,4 & 85,3 & 71,8 & 91,4 \\
\hline NPF & 0,3 & 0,5 & 0,7 & 3,8 & 3,1 & 4,7 & 2,74 & 2,72 & 4,18 & 2,5 & 0,3 & 4,7 \\
\hline $\mathrm{BOPO}$ & 87,2 & 92,2 & 92,5 & 93,7 & 91,3 & 95,2 & 91,9 & 91,7 & 99,2 & 92,7 & 87,2 & 99,2 \\
\hline
\end{tabular}

Sumber: Data sekunder yang diolah

Berdasarkan Tabel 8 dan Tabel 9 di atas mengenai keadaan kinerja keuangan Bank Umum Syariah Hasil Spin-off dan Bank Umum Syariah hasil Akuisisi periode 2015-2017 penulis ingin menjelaskan analisis statistik data secara deskriptif dari setiap variabel kinerja keuangan yaitu CAR,ROA,FDR,NPF, dan BOPO antara Bank Umum Syariah hasil Spin-off dan akuisisi menggunakan nilai rata-rata/Mean, nilai maksismum/Max, dan nilai minimum/Min.

\subsection{Capital Adequacy Ratio (CAR)}

Rasio Car adalah rasio kecukupan modal yang berfungsi untuk melihat kemampuan bank dalam menghadapi resiko kerugian. Besaran rasio CAR yang baik minimal sebesar $8 \%$ dan semakin besar maka semakin baik bank dalam menghadapi resiko kerugian.

Berdasarkan tabel 8 dan 9 dapat kita lihat nilai minimum variabel CAR Bank Umum Syariah hasil Spin-off sebesar 14,9 nilai ini adalah nilai lebih besar jika dibanding Bank Umum Syariah hasil Akuisisi yang nilai minimumnya sebesar 13,9. Nilai maksimum variabel CAR Bank Umum Syariah hasil Spin-off sebesar 22,5 nilai ini lebih kecil jika dibanding Bank Umum Syariah hasil Akuisisi yang nilai minimumnya sebesar 36,7.

Mean Bank Umum Syariah Hasil Spin-off sebesar 17,8 dan mean Bank Umum Syariah hasil Akuisisi 23. Maka jika di lihat dari nilai rata-ratanya kinerja keuangan Bank Umum Syariah hasil Akuisisi lebih baik karna bernilai lebih besar dibandingkan Bank Umum Syariah Hasil Spin-off. Nilai CAR yang bersar dapat menunjukan kinerja keuangan yang baik dan Bank Umum Syariah hasil Akuisisi berarti dapat memaksimmalkan nilai modal yang dimilikinya terhadap nilai aktiva yang dikalikan dengan resiko terlebih dahulu.

\subsection{Return of Asset (ROA)}

ROA adalah rasio yang digunakan untuk mengukur kemampuan bank dalam menghasilkan laba dengan membandingkan laba bersih sebelum pajak dengan total asset yang dimiliki bank, maka semakin besar rasio ROA berarti semakin baik bank dalam menggunakan seluruh asetnya untuk menghasilkan laba.

Berdasarkan tabel 8 dan 9 dapat kita lihat nilai minimum variabel ROA Bank Umum Syariah hasil Spin-off sebesar -8,09 nilai ini lebih kecil jika dibanding Bank Umum Syariah hasil Akuisisi yang nilai minimumnya sebesar 0,02. Nilai maksimum variabel ROA Bank Umum Syariah hasil Spin-off sebesar 1,4 nilai ini lebih besar jika dibanding Bank Umum Syariah hasil Akuisisi yang nilai minimumnya sebesar 1,2.

Mean Bank Umum Syariah Hasil Spin-off sebesar -1,5 dan mean Bank Umum Syariah hasil Akuisisi 0,78. Maka jika di lihat dari nilai rata-ratanya kinerja keuangan Bank Umum Syariah hasil Akuisisi lebih baik karna bernilai lebih besar dibandingkan Bank Umum Syariah Hasil Spin-off. Nilai 
ROA yang bersar dapat menunjukan kinerja keuangan yang baik dan Bank Umum Syariah hasil Akuisisi berarti dapat memaksimmalkan nilai pendapatan bersih sebelum pajak terhadap seluruh total aset yang ada.

\subsection{Financing to Deposit Ratio (FDR)}

Financing to Deposit Ratio (FDR) merupakan rasio yang mengukur kemampuan perbankan dalam memenuhi kewajiban jangka pendeknya atau biasa di sebut likiuditas dimana rasio ini di hitung dengan cara membandingkan pembiayaan yang disalurkan pada nasabah terhadap dana pihak ketiga yang dihimpun dari nasabah.

Berdasarkan tabel 8 dan 9 dapat kita lihat nilai minimum variabel FDR Bank Umum Syariah hasil Spin-off sebesar 80,2 nilai ini lebih besar jika dibanding Bank Umum Syariah hasil Akuisisi yang nilai minimumnya sebesar 71,8. Nilai maksimum variabel FDR Bank Umum Syariah hasil Spin-off sebesar 104,7 nilai ini lebih besar jika dibanding Bank Umum Syariah hasil Akuisisi yang nilai minimumnya sebesar 91,4.

Mean Bank Umum Syariah Hasil Spin-off sebesar 91,8 dan mean Bank Umum Syariah hasil Akuisisi 85,3. Maka jika di lihat dari nilai rata-ratanya kinerja keuangan Bank Umum Syariah hasil Spin-off lebih baik karna bernilai lebih besar dibandingkan Bank Umum Syariah Hasil Akuisisi, karena Bank Umum Syariah hasil Spin-off berarti dapat memaksimalkan nilai pembiayaan terhadap dana pihak ketiga yang ada, namun dengan nilai rasio FDR yang besar dapat beresiko terhadap kebutuhan likuiditas bank tersebut.

\subsection{Non Performing Financing (NPF)}

Non Performing Financing adalah rasio yang digunakan untuk mengukur kemampuan manajemen bank dalam mengelola kredit bermasalah yang ada dapat dipenuhi dengan aktiva produktif yang dimiliki oleh suatu bank. Rasio ini dikenal juga dengan rasio pemamfaatan aset.

Berdasarkan tabel 8 dan 9 dapat kita lihat nilai minimum variabel NPF Bank Umum Syariah hasil Spin-off sebesar 1,4 nilai ini lebih besar jika dibanding Bank Umum Syariah hasil Akuisisi yang nilai minimumnya sebesar 0,3. Nilai maksimum variabel NPF Bank Umum Syariah hasil Spin-off sebesar 4,5 nilai ini lebih kecil jika dibanding Bank Umum Syariah hasil Akuisisi yang nilai minimumnya sebesar 4,7.

Mean Bank Umum Syariah Hasil Spin-off sebesar 2,7 dan mean Bank Umum Syariah hasil Akuisisi 2,5. Maka jika di lihat dari nilai rata-ratanya kinerja keuangan Bank Umum Syariah hasil Akuisisi lebih baik karna bernilai lebih kecil dibandingkan Bank Umum Syariah Hasil Akuisisi. Nilai rasio NPF di dapat dari hasil perbandingan pembiayaan bermasalah terhadap pembiayaan yang ada sehingga semakin kecil nilai NPF kinerja keuangannya semakin baik.

Nilai NPF Bank Umum Syariah hasil Spin-off yang kurang baik ini dikarenakan nilai NPF Bank BJB Syariah sedang dalam kondisi tidak baik ini dikarenakan terjadinya kredit fiktif pada bank tersebut. Mengutip artikel dari website portal berrita CNN Indonesia yang berjudul Plt Dirut BJB Syariah Tersangka Kasus Kredit Fiktif. Badan Reserse Kriminal (Bareskrim) Polri menetapkan pelaksana tugas (Plt) Direktur Utama Bank Jabar Banten Syariah (BJBS) berinisial YG sebagai tersangka kasus dugaan korupsi pemberian kredit BJBS kepada debitur atas nama PT. Hastuka Sarana Karya periode 2014 hingga 2016. YG diduga tidak menaati prosedur saat memberikan kredit ke AW, selaku pimpinan PT HSK. Penyaluran kredit itu tanpa agunan. PT HSK butuh duit untuk menggarap proyek Garut Super Blok, pembangunan 161 ruko di Garut, kasus ini menimbulkan kerugian hingga mencapai Rp628 miliar.(Martahan,2017) 


\subsection{Beban Operasional dan Pendapatan Operasional (BOPO)}

Menghitung rasio BOPO berfungsi untuk melihat seberapa efisien bank melakukan operasionalnya dilihat dari pengeluaran operasionalnya. Keberhasilan bank didasarkan pada penilaian kuantitatif terhadap rentabilitas bank dapat diukur dengan menggunakan rasio biaya operasional terhadap pendapatan operasional.

Berdasarkan tabel 8 dan 9 dapat kita lihat nilai minimum variabel BOPO Bank Umum Syariah hasil Spin-off sebesar 86,8 nilai ini lebih kecil jika dibanding Bank Umum Syariah hasil Akuisisi yang nilai minimumnya sebesar 87,2. Nilai maksimum variabel BOPO Bank Umum Syariah hasil Spinoff sebesar 134,6 nilai ini lebih kecil jika dibanding Bank Umum Syariah hasil Akuisisi yang nilai minimumnya sebesar 99,2.

Mean Bank Umum Syariah Hasil Spin-off sebesar 103,3 dan mean Bank Umum Syariah hasil Akuisisi 92,7. Maka jika di lihat dari nilai rata-ratanya kinerja keuangan Bank Umum Syariah hasil akuisisi lebih baik karna bernilai lebih lebih kecil dibandingkan Bank Umum Syariah Hasil Akuisisi dimana semakin kecil nilai BOPO maka semakin baik. Nilai rasio BOPO yang $>100$ menunjukan kinerja keuangan yang tidak baik karena ini berarti biaya operasional yang dikeluarkan lebih besar di banding dengan pendapatan operasional yang didapat.

Nilai BOPO bank BJB Syariah pada tahun 2016 dan 2017 yang mencapai nilai >100 ini menunjukan bahwa kinerja keuangan keuagan BJB Syariah pada tahun 2016 dan 2017 sedang tidak sehat. Nilai BOPO yang tidak sehat ini dapat disebabkan dari nilai NPF BJB Syariah yang besar sehingga berpengaruh terhadap pendapatan operasional dan biaya operasional. Besarnya nilai pembiayaan macet yang dialami oleh BJB Syariah ini tentunya berpengaruh pada pendapatan operasional yang dimana sebagai lembaga keuangan yang fungsinya menghimpun dana dari pihak ketiga dan menyarulkan dana melalui pembiayaan pendapatan utama BJB Syariah di dapat dari pembiayaan.

\section{Penutup}

Pemisahaan Unit Usaha Syariah pada Bank Umum Syariah dapat dilakukan dengan dua cara yaitu pemhisanan dengan membentuk badan hukum baru (spin-off) dan pemisahan degan mengambil alih badan hukum yang sudah ada (Akuisisi). Hasil analisis deskriptif mengenai keadaan kinerja keuangan yang dilihat dari nilai nilai rata-rata CAR,ROA,FDR,NPF, dan BOPO. Bank Umum Syariah hasil Akuisisi memiliki nilai kinerja keuangan yang lebih baik dibandingkan Bank Umum Syariah hasil spin-off. Hasil uji beda penelitian ini menunjukan bahwa tidak terdapat perbedaan yang signifikan dari kinerja keuangan antara Bank Umum Syariah hasil spin-off dan Akuisisi dilihat yang dilihat dari rasio CAR, ROA,FDR,NPF, dan BOPO.

Unit Usaha Syariah yang ingin memisahkan diri dengan bank induk konvensionalnya dapat memilih cara pemisahan tergantung dengan kondisi dan kebutuhan internal banknya masingmasing, namun ketika kondisi bank mampu untuk melakukan akuisisi penulis menyarankan cara akuisisi karena dengan mengambil alih bank yang sudah ada, pihak bank yang mengambil alih akan mendapat keuntungan tidak perlu mengeluarkan biaya yang besar untuk membuat dan membesarkan bank yang baru. Dapat menggunakan sumberdaya, sistem, aset, peralatan, perlengkapan yang sudah ada sehinnga dapat mengurangi biaya pendirian bank dan dapat menawarkan margin yang lebih murah sehingga dapat bersaing dengan bank konvensional. Penelitian ini dapat menjadi referensi bacaan mengenai perkembangan perbankan syariah dan cara pendirian bank syariah, untuk peneliti selanjutnya dapat menambah variabel, menambah atau memperbaharui periode penelitian ini. 


\section{Daftar Pustaka}

Gozhali, Imam. (2016). Aplikasi Analisis Multivariate dengan Program SPSS 23. Edisi 8.Semarang: Universitas Diponegoro,

Ismal, Rifki. (2011). The Indonesian Islamic Banking Theory and Practices. Jakarta: Gramata Publishing

Izazi, Saraya dan Dina. (2016). Analisis Perbandingan Kinerja Kenangan Bank Umum Syariah Hasil Spin-Off dan Non Spin-Off Periode 2013-2015. Al/Jurnal l Ekonomi Syariah Teori dan Terapan Vol 3 No. 11,

Moin, A. (2003). Merger, Akuisisi, dan Divestasi. Edisi Pertama. Yogyakarta: Ekonisia.

Nurdin, A. A., Mai, M. U., \& Setiawan, S. Pola Kinerja Perusahaan Sesudah Merger dan Akuisisi serta Analisis Terhadap Faktor-Faktor yang Mempengaruhinya. Jurnal Riset Akuntansi dan Keuangan, 8(2), 431-446.

Rizqullah (2013). Pemiliban Metode Spin-off Unit Usaha Syariah Bank Umum Konvensional Menjadi Bank Umum Syariah di Indonesia. Jakarta : IEF Trisakti.

Setiawan, S., \& Sari, R. M. (2018). Rentabilitas Bank Umum Syariah Sesudah Spin-Off Berdasarkan Tipe Pemisahannya Di Indonesia. Amwaluna: Jurnal Ekonomi dan Keuangan Syariah, 2(1), 6987.

Simorangkir, O.P. (2004). Pengantar Lembaga Kenangan Bank dan Non Bank. Cetakan Kedua Bogor Selatan: Galia Indonesia

Sugiyono. (2009). Metode penelitian Bisnis. Jakarta: CV ALFABETA.

Syahrial, D. (2007). Manajemen Keuangan Lanjutan. Jilid Pertama, Jakarta: Mitra Wacana Media.

Wijaya, Denda, Lukman. (2009). “Manajemen Perbankan”Jakarta: Ghalia Indonesia.

\section{Website:}

Bank Aceh Syariah. (2012). Tentang Kami. Retrieved from Bank Aceh Syariah: http://www.bankaceh.co.id/?page_id=82

Bank Indonesia. (2011). Peraturan Perbankan : BI. Retrieved from BI.

Bank Indonesia. (2011, Februari 18). Peraturan Perbankan: BI. Retrieved from BI: https://www.bi.go.id/id/peraturan/perbankan/Pages/se_130611.aspx

Bank Mega Syariah. (n.d.). Tentang kami. Retrieved from Bank Mega Syariah: http://www.megasyariah.co.id/about-us/about-mega-syariah

Bank Muamalat. (2016). Profil. Retrieved from Bank Muamalat: http://www.bankmuamalat.co.id/profil-bank-muamalat

Bank Syariah Bukopin. (n.d.). Tentang kami. Retrieved from Bank Syariah Bukopin: https://www.syariahbukopin.co.id/id/tentang-kami/profil-perusahaan

Bank Syariah Mandiri. (2017). Sejarah. Retrieved from Bank Syariah Mandiri: https:/ /www.syariahmandiri.co.id/tentang-kami/sejarah\#

Bank Victoria Syariah. (2013). Profil. Retrieved from Bank Victoria Syariah: http://bankvictoriasyariah.co.id/page/sub/profil

BCA Syariah. (n.d.). Sejarah. Retrieved from BCA Syariah: http://www.bcasyariah.co.id/profilkorporasi/sejarah/

BJB Syariah. (2012). Sejarah. Retrieved from BJB Syariah: http://www.bjbsyariah.co.id/tentang- 
bjb-syariah/sekilas-bjb-syariah/

BNI Syariah. (n.d.). Sejarah. Retrieved from BNI Syariah: https://www.bnisyariah.co.id/id$\mathrm{id} /$ perusahaan/tentangbnisyariah/sejarah

BRI Syariah. (n.d.). Tentang kami. Retrieved from BRI Syariah: https://www.brisyariah.co.id/tentang_kami.php?f=sejarah

BTPN Syariah. (n.d.). Tentang kami. Retrieved from BTPN Syariah: https://www.btpn.com/id/tentang-kami/btpn-syariah

CNN Indonesia. (21, Nopember 2017). Nasional . Retrieved from CNN Indonesia: https://www.cnnindonesia.com/nasional/20171121091000-12-257027/plt-dirut-bjbsyariah-tersangka-kasus-kredit-fiktif

Editor, D. (2017, Mei 10). Macroekonomic. Retrieved from FEB UGM: https://macroeconomicdashboard.feb.ugm.ac.id/makna-car-roa-ldr-dan-bopo/

Hidayat, A. (2017, Maret 23). Mann-Whitney $U$ Test. Retrieved from Statistikan: https://www.statistikian.com

MayBank Syariah. (n.d.). Tentang kami. Retrieved from MayBank Syariah: http://www.maybanksyariah.co.id/

Panin Bank Syariah. (n.d.). Tentang kami. Retrieved from Panin Bank Syariah: https://www.paninbanksyariah.co.id/index.php/mtentangkami 